Abstracta Iranica Abstranica

Revue bibliographique pour le domaine irano-aryen

Volume 27 | 2006

Comptes rendus des publications de 2004

\title{
«La recomposition des identités et des territoires \\ en Iran islamique ». Annales de Géographie, n'638-639, (2004), pp. 511-530.
}

\section{Christian Bromberger}

\section{(2) OpenEdition}

Journals

Édition électronique

URL : http://journals.openedition.org/abstractairanica/6562

DOI : 10.4000/abstractairanica.6562

ISSN : 1961-960X

Éditeur :

CNRS (UMR 7528 Mondes iraniens et indiens), Éditions de l'IFRI

\section{Édition imprimée}

Date de publication : 15 mai 2006

ISSN : 0240-8910

Référence électronique

Christian Bromberger, « « La recomposition des identités et des territoires en Iran islamique ». Annales de Géographie, n638-639, (2004), pp. 511-530. », Abstracta Iranica [En ligne], Volume 27 | 2006,

document 336, mis en ligne le 02 janvier 2007, consulté le 25 septembre 2020. URL : http://

journals.openedition.org/abstractairanica/6562 ; DOI : https://doi.org/10.4000/abstractairanica.6562

Ce document a été généré automatiquement le 25 septembre 2020.

Tous droits réservés 


\title{
« La recomposition des identités et des territoires en Iran islamique $»$. Annales de Géographie, $\mathrm{n}^{\circ} 638-639$, (2004), pp. 511-530.
}

\author{
Christian Bromberger
}

Parmi les pays du Moyen-Orient et d'Asie centrale, l'Iran est celui où la diversité ethnique est la plus grande. Dans cet État «jacobin », où cependant moins de la moitié des habitants a le persan pour langue maternelle, les populations sont animées par un fort sentiment national iranien (en témoigne l'absence de revendication irrédentiste et de contestation frontalière dans un contexte régional pourtant troublé) et par un attachement à leur « ethno-région" qui prend de nouvelles formes dans un contexte «post-moderne » de migrations et d'urbanisation. Les identités ethniques demeurent vives mais sont déterritorialisées, la plupart des élites résidant désormais dans des métropoles éloignées de leur province d'origine. "Plus que le renouveau du fait ethnique, note l'A., le statut de la femme et la question de la liberté individuelle sont passés au centre des recompositions identitaires ». Réflexion intéressante et solidement argumentée sur l'Iran d'aujourd'hui, qui fait cependant apparaître, çà et là, la fragilité des constats et des pronostics à un moment donné («La République islamique veut minimiser son identité islamique », lit-on dans cet article publié en 2004).

\section{INDEX}

Thèmes : 12.1. Iran 
AUTEURS

CHRISTIAN BROMBERGER

Université de Provence - IFIR - Téhéran 